\title{
In situ carcinoma of the conjunctiva: surgical excision associated with cryotherapy
}

\author{
This article was published in the following Dove Press journal: \\ Clinical Ophthalmology \\ 18 September 2013 \\ Number of times this article has been viewed
}

\author{
Nicolás Crim \\ María Elena Forniés-Paz \\ Rodolfo Monti \\ Evangelina Espósito \\ Juan Pablo Maccio \\ Julio A Urrets-Zavalía \\ Department of Ophthalmology, \\ University Clinic Reina Fabiola, \\ Universidad Católica de Córdoba, \\ Argentina
}

Correspondence: Julio A Urrets-Zavalía Servicio de Oftalmología, Clínica Universitaria Reina Fabiola, Universidad Católica de

Córdoba, Argentina, Oncativo 1248 ,

Córdoba 5000, Argentina

Tel +5403514142150

Fax +54 035 I4I 42150

Email julioaurrets@gmail.com
Background: Although frequently underdiagnosed, squamous cell carcinoma is the most commonly observed malignancy of the conjunctiva. Multiple different treatments have been proposed to date. The purpose of this paper is to report our experience in the treatment of In situ carcinoma of the conjunctiva by surgical excision associated with cryotherapy.

Methods: Four eyes in four consecutive patients (two men and two women) of average age 53.2 (range 39-71) years at the time of diagnosis of ocular surface squamous neoplasia were treated by simple surgical excision and cryotherapy of the resulting surgical bed margins. In all cases, the diagnosis of in situ carcinoma was confirmed histopathologically.

Results: On histopathology, the edges of the surgical specimens were free of malignant cells in three of four patients. All patients showed excellent evolution without recurrence. Mean follow-up was 6.5 (range 2-14) years.

Conclusion: In situ carcinoma of the conjunctiva may be simply and successfully treated with surgical excision and cryotherapy.

Keywords: conjunctival squamous cell carcinoma, surgical excision, cryotherapy

\section{Introduction}

Ocular surface squamous neoplasia (OSSN) is a dysplasia of the conjunctival, limbal, or corneal epithelium, ${ }^{1}$ with a prevalence of $0.2-3.5$ cases in $100,000 .^{2}$ It is more frequently observed in individuals living in tropical regions ${ }^{3}$ and is rarely observed in central Argentina. OSSN includes conjunctival and/or corneal intraepithelial neoplasia, intraepithelial carcinoma of the conjunctiva, and conjunctival squamous cell carcinoma. $^{4}$

In 1978, Pizzarello and Jakobiec ${ }^{5}$ proposed a new denomination for conjunctival intraepithelial neoplasia, which was classified into mild and severe dysplasia. In the mild form, dysplastic cells comprise less than half of the epithelium layer, while in severe forms dysplastic cells comprise more than $50 \%$ of the epithelium. ${ }^{3,5}$ In situ carcinoma of the conjunctiva (ISCC) corresponds to the severe form of conjunctival intraepithelial neoplasia. ${ }^{6-7}$

Conjuctival intraepithelial neoplasia affects the epithelium layer without basal membrane invasion, ${ }^{8}$ while in conjunctival squamous cell carcinoma, the basal membrane and eventually other contiguous tissues are invaded, ${ }^{9-11}$ with rare distant metastasis. ${ }^{3,12-15}$

Many risk factors, such as chronic ultraviolet radiation exposure, ${ }^{12,14,16-18}$ human papilloma virus, ${ }^{3,19,20}$ human immunodeficiency virus, ${ }^{3,21-23}$ and tobacco smoking, ${ }^{12}$ 
have been associated with OSSN. Such agents may damage proteins, enzymes, and cells, leading to dysplastic cellular changes. Armstrong and Kricker ${ }^{24}$ hypothesized that chronic ultraviolet radiation exposure might alter limbal stem cells producing dysfunctional damage. Several authors have emphasized the role of integrins, proteins of the extracellular matrix that play a fundamental role in the development and homeostasis of most epithelial tissues, as being capable of suppressing proliferation of the epithelium under normal circumstances. ${ }^{25-27} \mathrm{Ng}$ et $\mathrm{al}^{17}$ proposed that ultraviolet radiation could damage extracellular matrix metalloproteinase and its regulators, producing dysfunctional and finally dysplastic changes, resulting in OSSN. In fact, there are several publications that mention molecular changes involved in squamous cell carcinoma. ${ }^{28-32}$

Symptoms of OSSN are nonspecific, and biomicroscopically can be confused with pingueculitis, pterygium, conjunctival keratosis, or chronic atypical conjunctivitis. ${ }^{3}$ Although a thorough slit-lamp examination is almost always adequate for diagnosis of OSSN, optical microscopy is necessary to confirm the diagnosis and to differentiate conjuctival intraepithelial neoplasia from conjunctival squamous cell carcinoma. $^{12}$

Many surgical procedures have been proposed, either as a single treatment ${ }^{12,14}$ or associated with different adjuvants like mitomycin $\mathrm{C},{ }^{7,33-35}$ ciclosporin $\mathrm{A},{ }^{35}$ topical 5-fluorouracil, ${ }^{36}$ beta ray strontium- $90,{ }^{37}$ cryotherapy, ${ }^{12,38}$ contralateral conjunctival graft, and oral mucosa or amniotic membrane transplantation. ${ }^{3}$

The purpose of this paper is to report our experience in treating ISCC with surgical excision in association with cryotherapy.

\section{Materials and methods}

Files of patients seen at our department with a presumed pretreatment diagnosis of OSSN and a histopathologic diagnosis of ISCC and treated by the same surgeon were reviewed. All patients lived in the periphery of Córdoba city in central
Argentina, generally undertook indoor activities, and had not been exposed to any particular pollutants. The two men had conventional office-based occupations and the two women performed home-related duties. Preoperatively, all patients received a comprehensive ophthalmologic examination.

Surgery was done under local anesthesia (subconjunctival infiltration of $2 \%$ lidocaine with epinephrine). Simple excision was performed for the entire lesion with a tumorfree margin of 1-2 mm and the underlying Tenon's capsule, followed by contiguous freezing cryoapplications with the retina probe along the resulting surgical bed margins, each cryoapplication being stopped after focal ice ball formation. In one case, the margins of the tumor visibly compromised the neighboring corneal epithelium, so a superficial laminar keratectomy was performed and contiguous freezing cryoapplications were performed over the denuded area. The conjunctival wound was sutured with separate stitches of nylon monofilament 9-0. Postoperative topical antibiotic and anti-inflammatory drops were used five times a day for 30 days. Surgical specimens from all patients were immediately fixed in formalin for 24 hours, embedded in paraffin, and stained with hematoxylin and eosin for study under light microscopy.

\section{Results}

Four eyes in four patients (two men and two women) of mean age of $53.2 \pm 14$ (39-71) years were operated on during the study period. Preoperatively, several nonspecific clinical signs were present, such as foreign body sensation (50\%), burning sensation (25\%), visible tumor (50\%), and red eye $(50 \%)$.

Biomicroscopically, one patient had an ulcerated pinguecula (Figure 1A and B), three patients had limbal or retrolimbal nodular leukoplakic lesions (Figure 2A), with one being a nodular leukoplakic keratinized lesion (Figure 3A) showing infiltration of the corneal epithelium (Figure 3B) that did not stain with topical fluorescein (not shown). In two patients, the location was nasal and in the other two

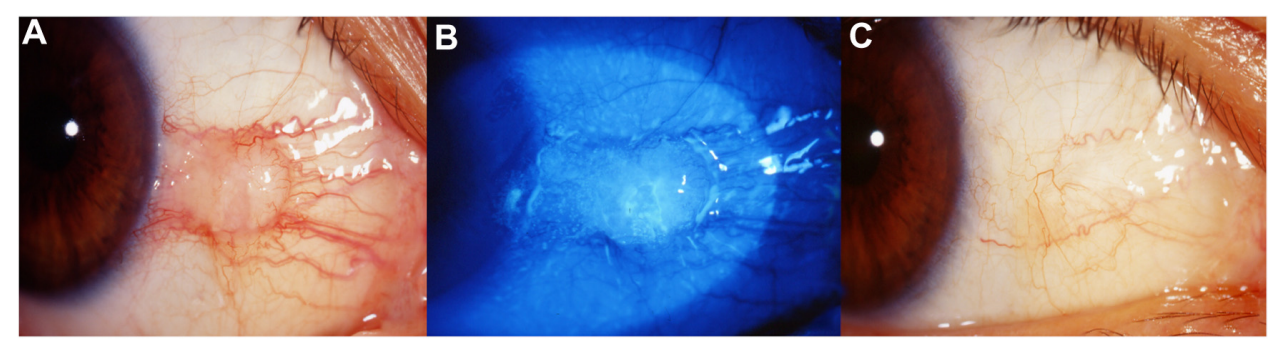

Figure I (A) Right eye of a 46-year-old woman showing a globular pinguecula-like nasal conjunctival lesion. (B) Same lesion stained with fluorescein showing surface ulceration in its apex. (C) Successful surgical result in the same eye after 2 years of follow-up. 

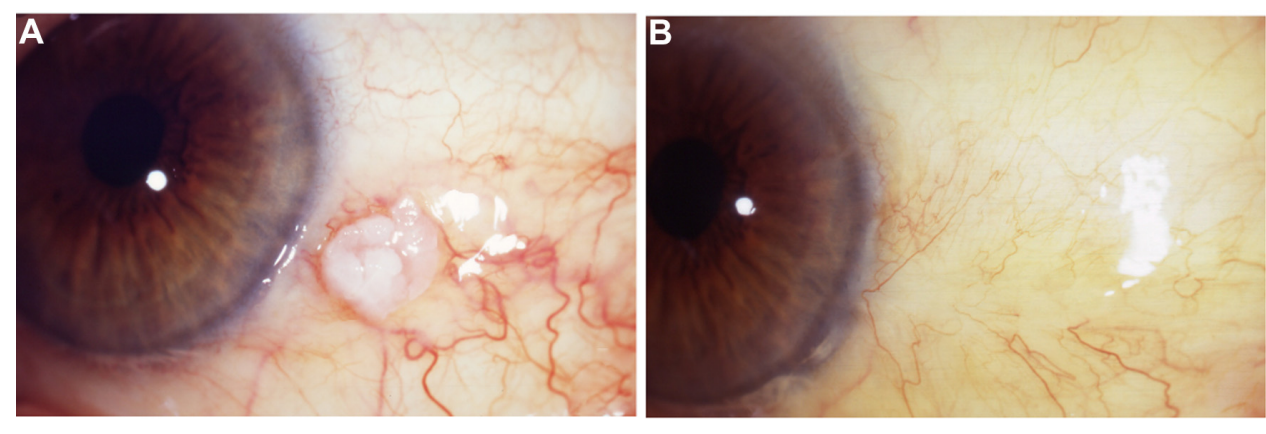

Figure 2 (A) Left eye of a 7I-year-old man showing a juxtalimbal leukoplakic irregularly nodular lesion with dilated perilesional conjunctival vessels. (B) Post surgical result in the same eye after 2 years of follow-up.

was temporal. Postoperatively, only mild to moderate local discomfort was observed for an average of 5 days.

The diagnosis of ISCC was established histopathologically, and all but one case showed tumor-free edges. The patient with preoperative corneal invasion (Figure 3A and B) had tumoral cells in the corneal margins of the excised specimen. Mean follow-up was 6.5 (2-14) years. None of the patients had recurrence, and all had excellent healing with discrete biomicroscopically visible scar (Figures 1C, $2 \mathrm{~B}$, and $3 \mathrm{C}$ ).

\section{Discussion}

ISCC may have nonspecific clinical signs and symptoms, and may be underdiagnosed. ${ }^{3,14,38}$ Clinically, it can be confused with pterygium, pinguecula, and papilloma, and it must be distinguished from other distinct conjunctival diseases such as solar keratosis, lymphoma, chronic blepharitis, conjunctivitis, atypical pannus, actinic keratosis, keratoacanthoma, and nevus ${ }^{39}$ The prevalence of ISCC in Argentina is not well defined, given that here it is an uncommon condition when compared with the frequency observed in India, ${ }^{40}$ Africa, ${ }^{23}$ Australia, ${ }^{12}$ or tropical regions. ${ }^{14}$

In our patients, clinical presentation was variable, as noted by other authors, ie, chronic sometimes ulcerated keratinized nodules or plaques affecting the interpalpebral bulbar conjunctiva and corneal epithelium, surrounded by conjunctival hypervascularization. ${ }^{3,38}$ ISCC is usually unilateral, but bilateral cases have also been reported. ${ }^{12}$

Macroscopically, ISCC has been described as leukoplakic, gelatinous, papilliform, nodular, or diffuse. ${ }^{12,41}$ Exfoliative cytology may help for a precise preoperative diagnosis of OSSN, but a thorough biomicroscopic observation is very frequently diagnostic. ${ }^{42}$ However, the definitive diagnosis is provided by histopathology. ${ }^{12}$

Different therapeutic associations have been described with good results, emphasizing the use of mitomycin $\mathrm{C}$ and topical ciclosporin to prevent recurrences ${ }^{35}$ However, use of immunomodulators is unsafe because of the risk of secondary damage to the ocular surface epithelium, such as punctate keratopathy, conjunctival hyperemia, eyelid and eye irritation, ${ }^{7,34,35}$ and loss of limbal cells after treatment. ${ }^{43}$ The use of topical 5 -fluorouracil has not shown good results in the long term, with multiple relapses and need for reoperations. ${ }^{36}$ Beta ray strontium- 90 has also been used with relative therapeutic success and some relapses, but with frequent side effects such as cataracts, glaucoma, surface ulcers, and episcleral telangiectasia. ${ }^{37,44}$

The addition of cryotherapy to surgical excision has been reported to be highly successful in the treatment of ISCC. ${ }^{12,14}$
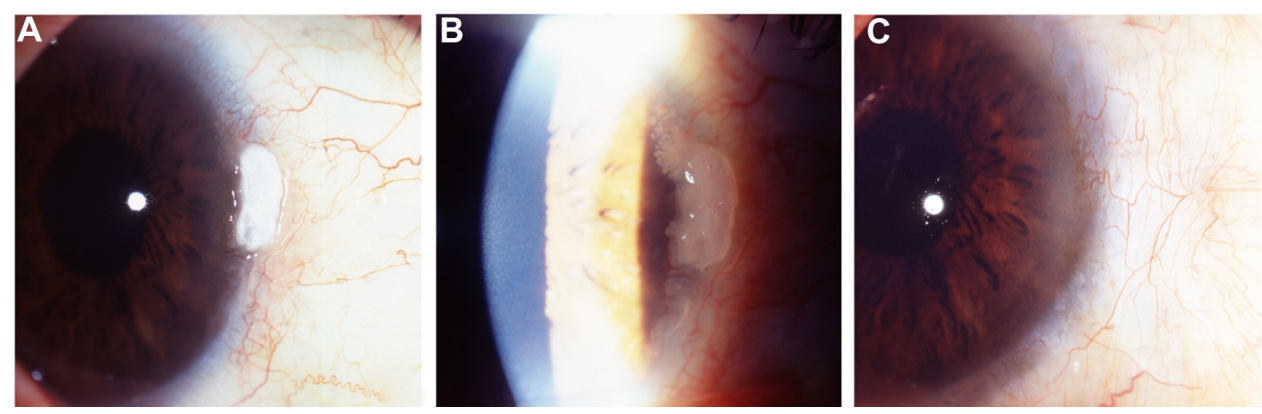

Figure 3 (A) Right eye of a 57-year-old man showing a limbal protruding and keratinized lesion with extension seeds to the prelimbal corneal epithelium, better observed with higher magnification and back scattered illumination (B). (C) The same eye 6 years later, with a smooth conjunctival scar and a discrete perilimbal opacity, without biomicroscopic signs of recurrence. 
In our series, no recurrences, side effects, or complications from treatment were observed with a single treatment session, even in the case with preoperative corneal infiltration and compromised margins of the excised lesion. Three (75\%) of our cases had incisional borders free of tumor and one had positive margins. In this case (figure 3), the tumor was situated in the nasal region. Galor et $\mathrm{al}^{45}$ observed that negative incisional margins and nasal localization indicate a low risk for developing recurrences of conjunctival neoplasia.

Our study has two important limitations. The first one is that the sample is small, principally because of the infrequent occurrence of ISCC in Argentina, especially in the central area of the country with its subtropical inland climate. The second limitation is the retrospective nature of this study. Randomized controlled trials to assess optimal treatment of this disease are needed in the settings where it occurs most frequently.

In conclusion, simple surgical excision associated with cryotherapy was effective for the treatment of ISCC in this small case series, with no adverse effects or recurrences after a long follow-up.

\section{Author contributions}

NC undertook ophthalmologic examination of patients and follow-up, acquisition, analysis, and interpretation of data, statistical analysis, and writing of the manuscript. MEF-P, $\mathrm{RM}$, and EE undertook acquisition, analysis, and interpretation of data, manuscript revision, and text editing. JPM performed analysis and interpretation of data, statistical analysis, and manuscript revision. JAU-Z was responsible for the conception and design of the work, ophthalmologic examination of patients and follow-up, treatment of patients, analysis and interpretation of data, writing of the manuscript and text editing, and final manuscript critical revision and correction.

\section{Disclosure}

The authors report no conflicts of interest in this work.

\section{References}

1. Lee GA, Hirst LW. Ocular surface squamous neoplasia. Surv Ophthalmol. 1995;39:429-450.

2. Mahoney MC, Burnett WS, Majerovics A, Tanenbaum H. The epidemiology of ophthalmic malignancies in New York State. Ophthalmology. 1990;97:1143-1147.

3. Shields JA, Shields AL. Atlas of Eyelid and Conjunctival Tumors. Philadelphia, PA: Lippincott Williams \& Wilkins; 1999.

4. Erie JC, Campbell RJ, Liesegang TJ. Conjunctival and corneal intraepithelial and invasive neoplasia. Ophthalmology. 1986;93:176-183.
5. Pizzarello LD, Jakobiec FA. Bowen's disease of the conjunctiva. A misnomer. In: Jakobiec FA, editor. Ocular and Adnexal Tumors. Birmingham, UK: Aesculapius; 1978.

6. Groossniklaus HE, Green WR, Luckenbach M, Chan CC. Conjunctival lesions in adults. A Clinical and histopathologic review. Cornea. 1987:78-116.

7. Prabhasawat P, Tarinvorakup P, Tesavibul N, et al. Topical $0.002 \%$ mitomycin $\mathrm{C}$ for the treatment of conjunctival-corneal intraepithelial neoplasia and squamous cell carcinoma. Cornea. 2005;24:443-448.

8. Gogi R, Nath K, Govil AK. Conjunctival epitheliomas and related lesions. Indian J Ophthalmol. 1976;24:1-8.

9. Aoki S, Kubo E, Nakamura S, et al. Possible prognostic markers in conjunctival dysplasia and squamous cell carcinoma. Jpn J Ophthalmol. 1998;42:256-261.

10. Iliff WJ, Marback R, Green WR. Invasive squamous cell carcinoma of the conjunctiva. Arch Ophthalmol. 1975;93:119-122.

11. Zimmerman LE. Ocular and Adnexal Tumours. Saint Louis, MO: C.V. Mosby Co; 1964.

12. McKelvie PA, Daniell M, McNab A, Loughnan M, Santamaria JD. Squamous cell carcinoma of the conjunctiva: a series of 26 cases. $\mathrm{BrJ}$ Ophthalmol. 2002;86:168-173.

13. Wiechens B, Swensson B. General metastases in squamous cell carcinoma of the conjunctiva. Klin Monbl Augenheilkd. 2002;219:813-816. German.

14. Tabbara KF, Kersten R, Daouk N, Blodi FC. Metastatic squamous cell carcinoma of the conjunctiva. Am J Ophthalmol. 1988;95:3:318-321.

15. Warner MA, Jakobiec FA. Conjunctival diseases: Tumors. In: Krachmer JH, Mannis MJ, Holland EJ, editors. Cornea. St Louis, MO: Anne Patterson; 1997;701-704.

16. Jaworski A, Wolffsohn JS, Napper GA. Detection, aetiology and management of conjunctival intraepithelial neoplasia. Ophthalmic Physiol Opt. 2000;20:371-380.

17. Ng J, Coroneo MT, Wakefield D, Di Girolamo N. Ultraviolet radiation and the role of matrix metalloproteinases in the pathogenesis of ocular surface squamous neoplasia. Invest Ophthalmol Vis Sci. 2008;49:5295-5306.

18. Newton R, Ferlay J, Reeves G, Beral V, Parkin DM. Effect of ambient solar ultraviolet radiation on incidence of squamous cell carcinoma of the eye. Lancet. 1996;347:1450-1451.

19. Tornesello ML, Duraturo ML, Waddell KM, et al. Evaluating the role of human papillomaviruses in conjunctival neoplasia. $\mathrm{Br} J$ Cancer. 2006;94:446-449.

20. Scott IU, Karp CL, Nuovo GJ. Human papillomavirus 16 and 18 expression in conjunctival intraepithelial neoplasia. Ophthalmology. 2002;109:542-547.

21. Mahomed A, Chetty R. Human immunodeficiency virus infection, Bcl2, p53 protein, and Ki-67 analysis in ocular surface squamous neoplasia. Arch Ophthalmol. 2002;120:554-558.

22. Cackett P, Gillies M, Leen C, Dhillon B. Conjunctival intraepithelial neoplasia in association with HIV infection. AIDS. 2005;19:351-352.

23. Ateenyi-Agaba C. Conjunctival squamous cell carcinoma associated with HIV infection in Kampala, Uganda. Lancet. 1995;345:695-696.

24. Armstrong BK, Kricker A. The epidemiology of UV induced skin cancer. J Photochem Photobiol. 2001;63:8-18.

25. Hynes RO. Integrins: bidirectional, allosteric signaling machines. Cell. 2002;110:673-687.

26. Janes SM, Watt FM. New roles for integrins in squamous-cell carcinoma. Nat Rev Cancer. 2006;6:175-183.

27. McCarty JH, Barry B, Crowley D, Bronson RT, Lacy-Hulbert A, Hynes RO. Genetic ablation of $\alpha$ v integrins in epithelial cells of the eyelid skin and conjunctiva leads to squamous cell carcinoma. Am J Pathol. 2008;172:1740-1747.

28. Auw-Haedrich C, Sundmacher R, Freudenberg N, et al. Expression of p63 in conjunctival intraepithelial neoplasia and squamous cell carcinoma. Graefes Arch Clin Exp Ophthalmol. 2006;244:96-103. 
29. Shepler TR, Prieto VG, Diba R, Neuhaus RW, Shore JW, Esmaeli B. Expression of the epidermal growth factor receptor in conjunctival squamous cell carcinoma. Ophthal Plast Reconstr Surg. 2006;22: $113-115$.

30. Fuller LC, Allen MH, Montesu M, Barker JN, Macdonald DM. Expression of E-cadherin in human epidermal non-melanoma cutaneous tumours. Br J Dermatol. 1996;134:28-32.

31. Scott RA, Dua HS, Joseph A, Haynes R, Snead D, Hand NM. E-Cadherin distribution in normal and dysplastic conjunctival epithelium. Eye. 2002;16:198-200.

32. Toth J, Karcioglu ZA, Moshfeghi AA, Issa TM, Al-Ma'ani JR, Patel KV. The relationship between human papillomavirus and p53 gene in conjunctival squamous cell carcinoma. Cornea. 2000;19:159-162.

33. Cartsburg O, Kersten A, Sundmacher R, et al. Treatment of 9 squamous epithelial carcinoma in situ lesions of the conjunctiva (CIN) with mitomycin $\mathrm{C}$ eyedrops in cytological and DNA image cytometric control. Klin Monbl Augenheilkd. 2001;218:429-434. German.

34. Frucht-Pery J, Rozenman Y. Mitomicin C therapy for corneal intraepithelial neoplasia. Am J Ophthalmol. 1994;117:164-168.

35. Zaki AA, Farid SF. Management of intraepithelial and invasive neoplasia of the cornea and conjunctiva: a long-term follow-up. Cornea. 2009;28:986-988.

36. Yeatts RP, Ford JG, Stanton CA, Reed JW. Topical 5-fluorouracil in treating epithelial neoplasia of the conjunctiva and cornea. Ophthalmology. 1995;102:1338-1344.

37. Elkon D, Constable WC. The use of strontium-90 in the treatment of carcinoma in situ of the conjunctiva. Am J Ophthalmol. 1979;87: 84-86.
38. Tunc M, Char DH, Crawford B, Miller T. Intraepithelial and invasive squamous cell carcinoma of the conjunctiva: analysis of 60 cases. Br J Ophthalmol. 1999;83:98-103.

39. Kiire CA, Srinivasan S, Karp CL. Ocular surface squamous neoplasia Int Ophthalmol Clin. 2010;50;3:35-46.

40. Manderwad GP, Kannabiran C, Honavar SG, Vemuganti GK. Lack of association of high-risk human papillomavirus in ocular surface squamous neoplasia in India. Arch Pathol Lab Med. 2009;133: 1246-1250.

41. Basti S, Macsai MS. Ocular surface squamous neoplasia: a review. Cornea. 2003;22:687-704.

42. Semenova EA, Milman T, Finger PT, et al. The diagnostic value of exfoliative cytology vs histopathology for ocular surface squamous neoplasia. Am J Ophthalmol. 2009;148:772-778.

43. Dudney BW, Malecha MA. Limbal stem cell deficiency following topical mitomycin $\mathrm{C}$ treatment of conjunctival-corneal intraepithelial neoplasia. Am J Ophthalmol. 2004;137:950-951.

44. Cerezo L, Otero J, Aragón G, et al. Conjunctival intraepithelial and invasive squamous cell carcinomas treated with strontium-90. Radiother Oncol. 1990;17:191-197.

45. Galor A, Karp CL, Oellers P, et al. Predictors of ocular surface squamous neoplasia recurrence after excisional surgery. Ophthalmology. 2012;119:1974-1981.
Clinical Ophthalmology

\section{Publish your work in this journal}

Clinical Ophthalmology is an international, peer-reviewed journal covering all subspecialties within ophthalmology. Key topics include: Optometry; Visual science; Pharmacology and drug therapy in eye diseases; Basic Sciences; Primary and Secondary eye care; Patien Safety and Quality of Care Improvements. This journal is indexed on

Submit your manuscript here: http://www.dovepress.com/clinical-ophthalmology-journal

\section{Dovepress}

PubMed Central and CAS, and is the official journal of The Society of Clinical Ophthalmology (SCO). The manuscript management system is completely online and includes a very quick and fair peer-review system, which is all easy to use. Visit http://www.dovepress.com/ testimonials.php to read real quotes from published authors. 